\title{
LUMUMBA, HAMMARSKJOELD, AND THE 1960 CONGO CRISIS: A case of international misunderstanding?
}

\author{
Jan BLOMMAERT \\ Seminar of Swahili and the Development of Languages of Developing Nations \\ Rozier 44 \\ 9000 Gent
}

\section{SUMMARY}

\section{LUMUMBA, HAMMARSKJOELD, AND THE 1960 CONGO CRISIS. A CASE OF INTERNATIONAL MISUNDERSTANDING?}

A number of influential works on the 1960 Congo Crisis, as well as most theoretical models of intercultural communication, consistently explain conflicts between culturally different participants in terms of features of ethnic communication style, cognition, value systems etc. A general picture emerges in which culture is seen as the cause of conflicts, misunderstandings, or communication breakdown. An analysis of six letters exchanged between Lumumba and Hammarskjoeld during one of the crucial episodes of the Congo Crisis reveals that ethnic features of communication style are the consequence, rather than the cause of conflicts.

KEY WORDS: Congo (Zaïre), history, linguistics 


\section{INTRODUCTION}

In the analysis of international conflicts in which an intercultural dimension is present, culture is very often seen as one of the main causes of the conflict. Authors such as Kochman (1981), Glenn (1981) and Ting-Toomey (1986) oppose two different, so-called ethnic styles of communication, and seek to explain the emergence and the development of the conflict in terms of incompatible features of both styles. Remarkably, this culturalism also seems to pervade much of the historiography of Africa's decolonization. Many clashes between the new African rulers and the former colonial ones are explained in terms of differing cultures, differing outlooks on reality and its political correlates such as leadership, democracy, human rights etc. (see Mazrui 1967 for a lucid and stimulating discussion).

Popular books on Congo's decolonization, among which Geerts 1979, Ruys 1985 and Vanderlinden 1985 rank as some of the most successful ones, are no exception to this. In all three of the forementioned books, the "cultural argument" as I would like to call it is used abundantly. Conflicting elements of Bantu vs. Western Culture are seen as crucial factors in the series of misunderstandings, mistakes and conflicts which makes up the Congo Crisis. A close look at how the concept of "culture" is used reveals a number of very striking inconsistencies (Blommaert 1990). First, a number of sweeping generalizations are made: Elements of personality, together with modes of political behavior (i.e. the way in which an individual takes on his role as a political person) and presumed group notions are put together under the label of , say, Bantu culture. Second, a number of equally sweeping reductions are made. Geerts' (1979) book explicitly adopts the view that insights in Bantu thinking (as outlined in Tempels' 'Bantu Philosophy') are the key to an understanding of what happened in the Congo Crisis. As such, he explains Mobutu's inclination towards personality cult as a typically 'Bantu' feature. Evidence for this is sought in statements made by Ghana's Nkrumah -- who was, for as far as I know, not a Bantu African. Also, Kasa-Vubu's decision to depose Lumumba is interpreted as a typically Bantu legalistic act (a law is a law, and the president is the boss) -- which begs the question as to why Kasa-Vubu remained aloof within a very typical Western interpretation of the role of a president during other phrases of the Congo Crisis. Was Kasa-Vubu less of a Bantu then? If not, was his attitude a product of 'acculturation'? And if so, how can this 'acculturated' view on the Congolese political system be made fit with the fundamental differences in political culture, proposed as the basis of Geerts' analysis?

In short, the culturalization of the history of the Congo Crisis seems to me a largely unjustified way of explaining the complex set of actions, developments and processes which is called the Congo Crisis. For one thing, it eclipses other areas in which explanations can be sought. However true the statement that every person is at all 
times a cultural being, it remains to be seen in how far 'culture' is a more or less clearly symbolized element in the concrete actions performed by the participants in an intercultural encounter (cf. Hinnenkamp 1990). In other words: How relevant is 'cultural difference' as a heuristic notion in explaining intercultural conflicts?

\section{TEXT, CULTURE AND HISTORY}

In order to illustrate the questionable nature of culturalized explanation, I will propose an analysis of one extended historical communicative event. At the apex of the Congo Crisis, on August 14 and 15 1960, Lumumba (the late Prime Minister of the Congo) and Hammarskjoeld (the late Secretary General of the United Nations) exchanged six letters. The letters constitute a discursive unity, in that they are concatenated by various arguments, they present a turntaking pattern in written interaction, and they have a clear starting and ending point in time. In the letters, Lumumba tries to discuss a number of objections he made against recent actions taken by Hammarskjoeld, but Hammarskjoeld refuses to enter into discussion. There is a clear stylistic shift in Lumumba's letters: From a cool, detached style in his first letter he shifts to a strongly emotional, involved style in his final letter. The full text of the letters, as reprinted from I.R.R.I. (1960, 790-795), is given in appendix.

The texts are obvious instances of intercultural communication: A Congolese Bantuculture member enters into communicative interaction with a Swedish Western-culture member, through the medium of written political communication in French. French is neither Lumumba's nor Hammarskjoeld's mother tongue. Furthermore, the stylistic shift in Lumumba's discursive style, as well as the propositional content of the letters and the amount of Face-threatening actions contained in them, reveal that the texts are obvious instances of conflict. So, according to all criteria of communicative typology, the texts are samples from a conflict in intercultural communication. A culturalized explanation would follow this lead: Given the typological clarity of the texts, the conflict must be sought at the level of intercultural differences in communicative style. What Lumumba and Hammarskjoeld write, as well as how they perceive their own and each other's texts, will be influenced directly by a different set of cultural assumptions about style in interaction and meaningconstruction. In other words, one would assume that Lumumba and Hammarskjoeld both view their act of communication on the basis of a different set of symbolic complexes, of cognitive backgrounds and attitudes. As a consequence, the conflict will be taken to arise from a totally different evaluation, a different cultural interpretation of what happens. In view of some of the features of the text, esp. Lumumba's shift towards personal and empathic style (which brings his final letter close to pre-Independence Congolese anti-colonial rhetoric: Rubango 1980), this would seem a logical and consistent line of explanation -- which I, however, will not pursue. 
My arguments for this are twofold. First, I take it that the common culturalized view on the Congo Crisis (of which particularly Lumumba was the victim) is a case of constructed history-ethnography. The historical account of the Congo-Crisis is blended with the ethnography of the Congolese political values and customs into a dubitable mix of presumed fact-fiction. To use Edmund Leach's words: "the (factual) past becomes a fiction invented by the ethnographer" $(1989,43)$. This means that the history of Congo's decolonization has essentially become an ethnography, which in turn entails that the behavior of the Congolese is abstracted onto the cultural level (i.e. the level on which culture becomes the major criterium of relevance). Lumumba's behavior is viewed in its own right, largely unaffected by "external" factors such as his being a politician, the war situation in his country, interactions with people other than Hammarskjoeld, and previous and subsequent episodes of the Crisis. A pragmatic perspective dictates that precisely these factors are of paramount importance in understanding the meaning conveyed in Lumumba's actions.

Second, as a consequence of the above, the cultural explanation must be interpreted as an element of power structure. History is what it is because it has been constructed in an authoritative way -- history reflects the way in which people want to think about themselves and about others. Again, history is fiction, but an authoritative fiction. My own stance with regard to history is that texts reveal historical processes in the sense that they must be seen as realizations of the power potential of the text producer (2). This means that what we read in the text must be interpreted as reflecting the way in which Lumumba and Hammarskjoeld were able to establish, maintain or alter social (power) relations vis a vis one another. This also means that a number of 'external' conditions become very important in interpreting the texts. Macrorelationships between groups, as they can be delineated from other texts produced by supporters and opponents in e.g. the U.N. General Assembly (see Eelen 1990, also Van Mensel 1975) become a major frame of interpretation, not only because they determine the position of the participants as representatives of these groups, but also because they determine a larger, general and biased frame of reference for the other parties in the event.

\section{THE HISTORICAL CONTEXT IN A NUTSHELL}

For a good understanding of what is actually dealt with in the letters, a short outline of the historical context is indispensable (see: I.R.R.I. 1960, 1961; Van Langenhove 1964).

- On July 11 (eleven days after independence), the Southern province of Katanga proclaimed its independence from the central government. The rebellion was led by Moïse Tshombe, and supported by the Belgians whose extensive invest- 
ments in the Katangese copper mining industry were threatened by Lumumba's intended nationalization policy.

- Lumumba invoked the help of the U.N., claiming that the Katanga secession was an international conflict opposing Belgians and Congolese. On July 14, the U.N. Security Council passed a first resolution on the Congo, the Belgians were requested to withdraw from Katanga, and the Secretary General was given full authority to set up a scheme of military cooperation between a U.N. detachment and the Congolese army. The military actions of the U.N. troops were submitted to approval by the Central Government.

- The Belgians contested the thesis of "international conflict", claiming that the Katangese crisis was an internal conflict opposing Congolese to Congolese. The Security Council passed a second resolution on July 22. In this resolution, the main points of the previous resolution were repeated (including the plenipotentiary status of the Secretary General in the field), but a request that all member states withheld from intervention in the crisis was added.

- Meanwhile, Congolese and U.N. troops prepared for an invasion of Katanga. Tshombe, confident because of the support he received from Belgium, the U.S.A., and some "moderate" African states, responded by a threat of total war in case of an invasion. This disconcerted Hammarskjoeld, and an American diplomat (R. Bunche) was sent to Elisabethville for negotiations with Tshombé. Congolese troops, preparing for an invasion, were disarmed by U.N. troops.

- On August 8, a third resolution was passed by the Security Council. Again, the main points were repeated. Article 3 stated that a military intervention in Katanga was necessary to re-establish law and order in the Congo; article 4 said that U.N. troops should never intervene in an internal conflict and should never influence the outcome of such conflicts.

- In the field, this resolution resulted in a stalemate. The U.N. detachment remained in its positions outside Katanga, and started control and security operations throughout the rest of Congo. This, of course, upset Lumumba: He stated that the U.N. had taken control over Congo, instead of intervening in Katanga. Meanwhile, Bunche continued his talks with Tshombe, and secret negotiations between Belgian officials and U.N. functionaries were initiated.

- The relations between the Central Government and the U.N. deteriorated drastically in mid-august. Lumumba, tired of losing time, ordered his troops to 
start an invasion in Katanga, the Katangese "Gendarmes" came under heavy pressure, until the U.N. troops intervened and imposed a ceasefire.

The six letters must be situated immediately after the U.N.-imposed ceasefire. Lumumba was handed a document which motivated the U.N. decision to intervene in the conflict. This motivation didn't satisfy Lumumba, and he writes this to Hammarskjoeld.

\section{THE LETTERS}

I have based my analysis upon the version of the letters published in I.R.R.I. 1960, 790-795 (3). The original letters were included into Hammarskjoeld's second report to the Security Council (numbered S/4417, add. 7.1.). All letters exchanged between the Central Government and the U.N. Detachment in the Congo were written in French.

\section{Letter 1: Lumumba to Hammarskjoeld. 14/8/1960}

Lumumba focuses upon the arguments for not invading Katanga, presented in Hammarskjoeld's memorandum. He develops a complex and technical argument, mainly based upon readings of the U.N. Security Council resolutions, against Hammarskjoeld's position. Next, he formulates 5 concrete requests for action. The tone of the letter is stern but diplomatic, Lumumba constantly uses "the Government of the Republic of Congo" as his speaker-qualification. In Lakoff's (1979) scale, the style of this letter would rank as "clarity".

\section{Letter 2: Hammarskjoeld to Lumumba. 15/8/1960}

Hammarskjoeld's reply is short and evasive. A first paragraph paraphrases Lumumba's letter, qualifying its content as "allegations made against the SecretaryGeneral of the U.N.O.". Next, Hammarskjoeld states a blunt refusal to discuss the issue here and now; Lumumba's letter will be distributed in the U.N. Security Council for discussion. He finally mentions a number of additional facts disclaiming some of Lumumba's remarks. 


\section{Letter 3: Lumumba to Hammarskjoeld. 15/8/1960}

Lumumba's second letter addresses the issue of "allegations". He asserts the factuality of his earlier claims, and stresses his thesis that Hammarskjoeld's actions run counter to the decisions of the U.N. Security Council. Lumumba still uses "the Government of the Republic of the Congo" as his speaker-qualification.

\section{Letter 4: Hammarskjoeld to Lumumba. 15/8/1960}

Hammarskjoeld's second reply is even shorter than his first one. In his introduction. he "assumes that (Lumumba's) letters have been approved by his Cabinet" -implying this is not the case. Next, he repeats his refusal to discuss the matter. and reaffirms that Lumumba's letters will be the subject of a discussion in the Security. Council. He mentions his departure for New York, scheduled for the same evening. and provides some new arguments against Lumumba's complaints.

\section{Letter 5: Lumumba to Hammarskjoeld. 15/8/1960}

Lumumba reacts swiftly. He denies that any of his earlier statements would be false or mistaken, he even adds some background information to fortify his claims. In this letter, we find derogatory qualifications of the Swedish military personnel (relations with the Belgian King), the Belgian Secretary of Foreign Affairs. Pierre Wigny (director of various Katanga-based mining companies and conspirator behind the Katangese coup), and Tshombe (strawman of the Belgians and leader of the rebellion). Lumumba ends by stating that the people and the Government of the Congo have lost their confidence in Hammarskjoeld. He asks for a delay in Hammarskjoeld's departure for New York, such as to enable a Congolese delegation to travel aboard the U.N. plane. In this letter, Lumumba uses the 1st singular for his speaker qualification.

\section{Letter 6: Hammarskjoeld to Lumumba. 15/8/1960}

Hammarskjoeld notes Lumumba's loss of confidence in him. He minimizes the impact by suggesting that this decision is based upon Lumuba's allegations, which are still open for debate in the Security Council. He refuses to delay his departure 
because the Security Council will not meet over the issue before the arrival of the Congolese delegation.

\section{ANALYSIS: CULTURE AND STRATEGY}

When we take the correspondence in its whole, two features stand out as particularly remarkable. First: the escalation towards anger and ad hominem in Lumumba's communication (esp. his third letter). Second: Hammarskjoeld's repeated refusal to discuss matters with Lumumba.

\subsection{Getting angry: what is culture and what is authority?}

Lumumba's shift towards a personal and emotional style could be interpreted by some as typically African (or typically Black) style for that matter. According to Kochman (1981), Black negotiation style is issue-centered, confronting and personal. The distinction between person and function is supposed to be a difficult one for blacks. Indeed, Lumumba's letters carry lots of features typical of Black negotiation style: He becomes personal, disregarding the status and function of Hammarskjoeld and himself, his argument is indeed truth-centered and not consensus-centered and so forth. Specifically the confrontational character of Lumumba's rhetoric could be noted as being a feature of black ethnic style. But obviously, there is more to say about anger. Anger or emotion can be triggered by universal patterns of Face management in the interaction. For Lumumba, the stakes are high: If the U.N. doesn't let the governmental troops invade Katanga, his position would be in great danger (subsequent events have proven the reality of this danger). Lumumba is understandably impatient, and his getting angry at Hammarskjoeld's refusal to discuss the matter could be only human. His anger is also fed by the facts he knows about Hammarskjoeld, and which he reveals in his third letter: It has by now become clear that Hammarskjoeld was not a neutral third party in the conflict. The stalemate he had created in the field was -- if not intentionally, surely in effect -- an advantage for Tshombe and detrimental to Lumumba. It allowed Mobutu to prepare his coup d' état which was to culminate in Lumumba's assassination some months later. Lumumba experiences Hammarskjoeld's dry refusal as guided by a pro-Tshombe attitude, hence his hammering on the "facts" that contradict Hammarskjoeld's arguments. Lumumba opposes Hammarskjoeld's claims to authority of what can appropriately be discussed, because he suspects Hammarskjoeld to take a partisan point of view. His partisan attitude is in contradiction with the role-relationship agreed upon before, and stipulated in the resolutions. Therefore, Lumumba interprets claims to authority by Hammarskjoeld as unjustified. We can trace this implicitly in the legalistic argumentation developed in Lumumba's first letter, and explicitly in 
his third letter. The issue here is a competition for something like "official (or institutional) Face".

A second factor is tolerance. The evaluation of emotion is discourse-strategic, and motivated by overall tolerance. Clearly, the new York Times is likely to judge Kruschtchev's emotion negatively (as noted by Verschueren (1985)), and e.g. Spaak's positively, since the former is an enemy and the latter an ally. The threshold of acceptability of emotion (or deviance of a presumed norm in general) in discourse, especially in formal international settings, is marked by the boundaries of groupmembership and alliances. Therefore, there isn' $t$ something like an established or absolute norm of international debating style, imposing detachment and matterof-factism on the participants. The norm is negotiated, depending upon role-relationships and therefore above all on authority. When the norm is invoked as an argument, like in Hammarskjoeld's second letter where he sarcastically suggests that Lumumba doesn't follow the rules of politics ("je suppose que vos lettres ont été approuvées par le Conseil des Ministres..."), it is always (a) an evasive move, aimed at escaping Face-threatening situations by qualifying the Face-threatening act as "against the rules", or (b) an authority-enforcing move, qualifying one's own statements as superior to the other's. Invoking the norm is a form of authority simply because one must have the power to define the norm in order to be able to use it as an evaluative criterium in discourse. Using the norm as an argument means marking the threshold of acceptability, mostly narrowing it towards one's own behavior.

\subsection{How to get a Prime Minister angry}

Let me ask an impertinent question: How do you get a Prime Minister angry? I think you would stand a good change by denying his authority -- and this is what happens to Lumumba. We have noted in the survey of the historical background that Hammarskjoeld held a plenipotentiary status with regard to his activities in the field. His only responsibility was to the U.N. Security Council, and even there, he held great authority. If the Security Council wanted to express disagreement with one of Hammarskjoeld's actions or decisions, this had to be done by revoking him from his post as commander of the detachment in the Congo (Van Langenhove 1964). This meant that the Secretary-General would be attacked directly in his authority as Secretary-General, which would almost certainly have provoked his resignation. Within the precarious balance of power in the U.N. during the Cold War days, in which Hammarskjoeld played a crucial pro-Western role, and in which the position of the Secretary-General was under heavy fire from the Soviet side, this would have been highly unlikely. In sum, Hammarskjoeld's power was close to unlimited, he could in practice do as he saw fit. 
The only formal restriction upon his formidable power and autonomy was the obligation, stipulated in the resolutions, that Hammarskjoeld should work in close collaboration with the Lumumba Government, and that he should submit his actions for approval to this Government. That he did not always do this, even more, that he did this only very selectively while at the same time hiding most of his secret diplomacy from Lumumba's eyes, appears to be an established fact for Lumumba. Lumumba was the only one who really contested it. His protests were, however, interpreted as a "commie's" radical and intentional misreadings of the SecretaryGeneral's good faith, and were dismissed as nonsense or irrelevant.(4)

What we witness in the letters is therefore a tremendous clash of two claims of authority. The one by Lumumba is based on the clear statement in the resolutions, obliging Hammarskjoeld to seek approval with the government; the one by Hammarskjoeld is based upon his awareness that he was de facto autonomous and so immensely powerful that nobody could force or forbid him to do anything. This awareness, combined with Hammarskjoeld's basic pro-Western (and therefore antiLumumba) feelings, enabled him to propose his own partisan point of view as the official one. He could discard Lumumba's protests because he assumed that safeguarding the Congo within the western camp was in the international community's best interest. His partisan anti-communist point of view was sufficient justification for his denial of Lumumba's authority. Of course, Hammarskjoeld could not explicitly state this. In his letters, he had to select more subtle forms of authority enforcement to counter Lumumba's claims of authority. Some of these are quite easily detectable. First of all, of course, Hammarskjoeld uses a lot of normdominance. I have already mentioned his referring to the political procedure, requiring that official communications should be distributed among the Cabinet members and should be subject to their advice and approval. Throughout his letters, Hammarskjoeld makes frequent references to the correct procedure to be followed. He states in each one of his letters that the matter is for the Security council to be discussed, and cannot be decided by himself. He underscores these statements with subtle modal expressions such as "il va sans dire", "évidemment", "naturellement" etc. This norm-dominance creates a situation in which Lumumba has to make up for his supposed lack of knowledge of the procedure. This situation is reinforced by the use of information-dominance. In each one of his letters Hammarskjoeld counters Lumumba's factual arguments by referring to sources of information which Lumumba seems to have overlooked (cf. in Hammarskjoeld's third letter: "Je vous refère au mémorandum explicatif qui vous a été transmis par M. Bunche. Vous y trouverez toutes les indications nécessaires"). Here also, Hammarskjoeld creates a situation in which Lumumba appears to be the less informed, the weaker party.

An additional effect of exercising these two forms of dominance seems to be that the other participant loses control over at least part of the repertoire of possibly available 
arguments and strategies. When Hammarskjoeld gives the impression that his factual knowledge is more extensive than Lumumba's, Lumumba loses the possibility to use factual knowledge as an argument. The same goes for norm: Lumumba is unable to use the correct procedure as an argument from the moment when Hammarskjoeld insinuates that Lumumba doesn't really know what the right procedure is. In other words, the range of possible counter-offensive measures is restricted by the use of forms of dominance, and Lumumba turns to what is left: pillow-talk on secret negotiations between Hammarskjoeld and the Belgians, emotion, insults and radicalism. The Prime Minister has become angry, because anger is the only argument left for him. Such is the reduction of his authority by Hammarskjoeld.

\subsection{The power of taking a plane}

In his final letter, Lumumba requests Hammarskjoeld to delay his departure by plane for New York, such as to allow the Congolese delegation to join the Secretary General on the trip to the Security Council. Hammarskjoeld bluntly refuses this favor. assuring Lumumba that nothing will happen in New York prior to the arrival of the Congolese delegation.

In this seemingly trivial request and refusal resides a major power strategy. which can only be understood if one takes the six letters in their whole, and relates them to time. The letters must have been written in an overall time span of something like 24 hours. Probably as an element of standard procedure, each one of the letters makes reference to the time of arrival and the dating of the previously received letter. In these references we notice that the reaction time, measured between responsive moves of the participants, gradually decreases:

LH1: "aide-mémoire du 12 août 1960" -- 2 days

HL1: "votre lettre de cette date" -- 1 day

LH2: "votre lettre de ce jour" -- same day (a few hours)

HL2: "votre lettre du 15 août en réponse à ma lettre du même jour: (première communication reçue aujourd'hui à midi") -- same day (less than one hour)

LH3: "à l'instant votre lettre de ce jour répondante à celle que je vous ai envoyée il y a une heure" -- same day (a few minutes)

HL3: "troisième lettre de ce jour vient d'être reçue" -- same day (a few minutes) 
Whereas each participant's first letter comes at a somewhat normal tempo, a tremendous crescendo appears from LH2 onwards. The two final letters must really have been prompt reactions to incoming information, which can be witnessed from Lumumba's explicit reference to "il y a une heure" (the time interval between sending off LH2, receiving HL2 and writing LH3) and verbalizations such as "à l'instant" and "vient d'être reçue". Why this acceleration of interaction tempo?

The clue lies with the plane. Lumumba knows that Hammarskjoeld has his departure scheduled for the evening of the 15th. Hammarskjoeld confirms this in HL2, and again in HL3. This means that there is a fixed ending point to the interaction, dictated by Hammarskjoeld's scheduled flight to New York. So if Lumumba wants to get his point across to Hammarskjoeld, it has to happen before this ending point. It is not surprising therefore that Lumumba feels a sense of urgency. This urgency is exploited by Hammarskjoeld through manipulating interaction time. First, it is his own schedule, of which he is in control, which seems to dictate the end of the interaction. Lumumba's request for some delay is denied. Subjective time (Hammarskjoeld's personal schedule of activities) is granted the status of objective, non-negotiable time. Second, Hammarskjoeld refuses to let Lumumba get his point across, by stonewalling the issues he raises. In other words, he reduces interaction time for Lumumba by allotting gradually less time for the same content -- he makes Lumumba "lose" time in a very literal way. In LH3, Lumumba remains with as big an issue as on the evening of the $14 \mathrm{th}$, only he has considerably less time to discuss the matter with Hammarskjoeld because of the scheduled flight.

The reduction of interaction time appears to be directly related to the stylistic shift we witness in Lumumba's letters. Ample interaction time (LH1) is reflected in a cool, legalistic style in which "correctness" is the issue. As soon as the afternoon of the 15th breaks, and only a few hours are left to discuss because of Hammarskjoeld's authoritative confirmation of his departure and his refusal to go into the matter hic et nunc, Lumumba gradually shifts to an ethnic style. Lumumba seems to make this shift automatically, logically, his anger is real.

Referring to what I advanced about the way in which texts reveal the power potential of the text producer, and the way in which texts reflect social and historical processes, the following symbolization appears here. Lumumba's style becomes ethnically marked as soon as he's thrown back in a colonial interaction situation. His discourse in LH3 is very close to the kind of anti-colonial rhetoric he practised before independence, so somewhere and somehow he must have associated the present interaction situation with pre-independence ones. Whereas he is an authoritative Prime Minister in LH1, and behaves as such, the denial of his authority in Hammarskjoeld's responses puts him back in a disempowered, strongly inferior position, in which only anti-colonialist discourse seems to fit. To me therefore the 
ethnic element in Lumumba's style seems to be totally and directly connected to the power-relationship present in the interaction. "Culture", to use the classical term, is a consequence, not a cause.

\section{CONCLUSION}

This exercise was aimed at demonstrating a common fallacy in much of what is done in the field of intercultural communication. Problemizing "culture" (in whatever definition it is presented -- see Blommaert 1990 for a survey) as an a priori influence on intercultural encounters is turning things upside down, according to the evidence I have gathered in studying documents on the Congo Crisis, Swahili political style and contemporary minority policies in Belgium. "Culture" (which in my narrow definition stands for features of ethnic style symbolized in interaction and tangible in comparisons of ingroup and outgroup rhetoric) is an emergent phenomenon, not an a priori. It is triggered by discourse-internal moves, and it is governed by power-relations established and negotiated between the participants. It is not surprising to me that culture is a very relevant concept for the superior party in an interaction, while it is not available as an argument to the inferior one.

Second, I wanted to demonstrate how a discourse-analytical tool such as the one presented here can serve in reassessing seemingly established, "historical" facts about the Congo Crisis. History is written by the victors -- it is ideology and part of the identity constructed for both the subject and the object. I am convinced that a close scrutiny of texts related to the Congo Crisis will reveal a lot of the ideology behind the history.

\section{NOTES}

1.The gist of the paper was originally presented as a lecture to the International Pragmatics Conference, Antwerp, August 1987. I thank Jef Verschueren and Jacob Mey for help, advice and comments, and Gino Eelen for a number of stimulating discussions on this subject. Research on 
this topic was made possible by a grant from the Belgian Fund for Collective Fundamental Research (F.K.F.O.).

2.This view is of course heavily influenced by Fabian (e.g. 1974, 1983, 1990) and Mey (1985).

3. I found another version of these letters in Volodine 1962, 54-63. There were some slight differences between the version I used here and Volodine's. One particularly disturbing difference I found in Volodine's rendition of HL3. In the second paragraph Volodine's version reads: "référez-vous" instead of "je vous réfère". Using the imperative mood instead of a polite declarative is so out-of-character in Hammarskjoeld's style that it compels me to suspect that Volodine has edited this letter such as to picture Hammarskjoeld as an undiplomatic figure. I considered the I.R.R.I. version, despite its overall partisan attitude, the more reliable one.

4.That Hammarskjoeld was perceived as a "commie" by, inter alia, the C.I.A. is convincingly demonstrated by Ambrose $(1985,289)$. Western sources in general adhere to the view of Lumumba's being inclined to favor the communist bloc; African sources on the other hand (e.g. Fanon 1967, 191ff.) emphasize the nationalist and non-alligned basis of Lumumba's views and policy.

\section{REFERENCES}

Ambrose, Steven E.

1985, Rise to Globalism: American foreign policy since 1938. Harmondsworth: Penguin

Blommaert, Jan.

1990, "How much culture is there in intercultural communication?". In J. Blommaert \& J. Verschueren (eds.). 1990, The Pragmatics of Intercultural and International Communication. Amsterdam: John Benjamins

Eelen, Gino.

1990, "Standpunt en Perspektief. Een sociolinguïstische studie van politiek taalgebruik in een internationaal-politieke setting (U.N.O.) rond de Congolese onafhankelijkheid in 1960". Lic. Diss., University of Gent

Fabian, Johannes.

1974, "Genres in an emerging tradition. An ethnographic approach to religious communication". 
In A.W. Eister (ed.). 1974, Changing Perspectives in the Scientific Study of Religion. New York: Wiley, pp. 249-272

1983, Time and the Other. How anthropology makes its object. New York: Columbia University Press

1990, History From Below. Amsterdam: John Benjamins

Fanon, Franz.

1967, Toward the African Revolution. New York: Monthly Review Press

Geerts, Walter.

1979, Binza 10. Gent: Story Scientia

Glenn, Edmund.

1981, Man and Mankind. Conflict and communication between cultures. Norwood: Ablex

Hinnenkamp, Volker.

1990. "The economy of intercultural communication: Talking a person into interethnic distinction". In J. Blommaert \& J. Verschueren (eds.). 1990, The Pragmatics of Intercultural and International Communication. Amsterdam: John Benjamins

I.R.R.I. (Institut royal des Rélations internationales).

1960, La Crise congolaise. 1er Janvier 1959 - 15 Août 1960. Bruxel les: I.R.R.I. (= Chronique de Politique étrangère $13,4 / 6$ )

1961, Evolution de la Crise congolaise de Septembre 1960 à Avril 1961. Bruxelles: I.R.R.I. (= Chronique de Politique étrangère 14, 5/6)

Kochman, Thomas.

1981, Black and White Styles in Conflict. Chicago: University of Chicago Press

\section{Lakoff, Robin T.}

1979, "Stylistic strategies within a grammar of style". Annals of the New York Academy of Sciences 327, pp. 53-78

Leach, Edmund.

1989, "Tribal ethnography: Past, present, future" In E. Tonkin, M. Mc. Donald \& M. Chapman (eds.) . 1989, History and Ethnicity. London: Routledge. pp. 34-47

Mazrui, Ali A.

1967, Towards a Pax Africana. Chicago: University of Chicago Press

Mey, Jacob.

1985, Whose Language? A study in linguistic pragmatics. Amsterdam: John Benjamins

Rubango wa Rubango.

1980, Les Principales Tendances du Discours Politique zaïrois. 1960- 1965. Bruxelles: ASDOC/CEDAF 
Ruys, Manu.

1985, 25 Jaar Congo-Zaïre. Brussel: Grammens

Ting-Toomey, Stella.

1986, "Conflict communication style in Black and White subjective cultures". In Y.Y. Kim (ed.)

1986, Interethnic Communication, Current Research. Beverly Hills: Sage, pp. 75-88

Vanderlinden, Jacques.

1985, La Crise congolaise. Bruxelles: Editions Complexe

Van Langenhove, Fernand.

1964, Le Rôle proéminent du Sécretaire général dans l'Opération des Nations Unies au Congo. Bruxelles: I.R.R.I., Den Haag: Martinus Nijhoff

Van Mensel, Alfons.

1975, Het Handvest van de Organisatie van Afrikaanse Eenheid. Brussel: Elsevier Sequoia

Verschueren, Jef.

1985, International News Reporting. Metapragmatic metaphors and the U2. Amsterdam: John Benjamins

Volodine, Lev.

1962, Patrice Lumumba, Champion de la Liberté africaine. Moscou: Editions du Progrès 


\title{
COPIES FROM LUMUMBA - HAMMARSKJOELD LETTERS
}

\author{
DOCUMENT O.N.U. S/441/Add. 7, 15 août 1960, "Additif N7" \& "Additif N7 \\ Additif N1" $\left.{ }^{*}\right)$
}

\section{Lettrk: en date du 14 aOUt 1960 adressée au Ministre des Affaires étrangères de la République du Congo par le Secrettaire génteral.}

A mon retour d'Élisabethville et de Kamina, où je me suis rendu de New York avec toute l'urgence possible afin de mettre en auvre, sans aucun délai, la résolution du Conseil de Sécurité du 9 août 1960, je voudrais faire rapport au Gouvernement de la République sur l'état d'exécution des résolutions du Conseil auquel les Nations Unies sont maintenant arrivées. J'exprime ce désir me référant au voeu du Conseil de Sécurité de prendre en consultation avec le Gouvernement de la République du Congo les mesures nécessaires en vue de fournir à ce gouvernement l'assistince militaire dont il a besoin.

Je vous prie, Excellence, d'agréer, l'expression de ma très haute considération.

\section{Le Secrétaire Général des Nations Unies Signé: Dag Hammarskjold}

\section{Lettre en date du 14 aout 1960 adresséte au Secrétaire Général par l.e Premier Ministre de la Républ.ique du Congo}

J'ai l'honneur d'accuser réception de votre aide-mémoire qui m'a êté communiqué le 12 août 1960 et libellé comme suit : "Aide-mémoire sur la mise en ceuvre de la résolution du Conseil de Sécurité en date du 9 août 1960 - paragraphe 4 du dispositif " .

Comme il l'a exposé à M. le Dr Bunche, le Gouvernenent de la République du Congo ne peut en aucune façon marquer son accord avec votre interprétation personnelle qui est unilatérale et erronée; en effet, la résolution du 14 juillet 1960 déclare textuellement que le Conseil de Sécurité vous " autorise de fournir au Gouvernement de la République du Congo l'assistance militaire dont il a besoin ". Ce texte précise que vous le ferez - en consultant mon gouvernement. Il est donc clair qu'en ce qui concerne son intervention au Congo, l'O.N.U. n'agit pas comme une organisation neutre, mais que le Conseil de Sécurité met tous ses moyens à la disposition de mon gouvernement. II résulte de ces textes clairs que, contrairement à votre interprétation personnclle, les forces des Nations Unies peuvent être utilisées " pour réduire le Gouvernement rebelle

(*) Also published in: La crise congolaise, ler janvier 1959 - 15 août 1960 (Chronique de Politique étrangère, vol. XIII, ${ }^{\circ} 4$ à 6 ), Bruxelles, Institut royal des Relations internationales, 1960 , pp. 790-795. 
du Katanga ", que mon gouvernement peut faire appel aux services des Nations Unies pour transporter des représentants civils et militaires du Gouvernement central au Katanga, à l'encontre du Gouvernement provincial du Katanga, et que les forces des Nations Unies ont le devoir de protéger le personncl civil et militaire qui représente mon gouvernement au Katanga. Le paragraphe 4 de la résolution du Conseil de Sécurité du 9 août 1960 que vous invoquez pour contester ce droit ne peut être interprété en faisant abstraction des deux résolutions antérieures. Cette troisième résolution que vous citez n'est que le complément des deux précédentes qui, d'ailleurs, restent entières. La résolution à laquelle vous vous référez confirme les deux premières. Je cite : " le Conseil de Sécurité confirme l'autorité donnée au Secrétaire Général par lés résolutions du Conseil de Sécurité des 14 et 22 juillet 1960 et le prie de continuer à s'acquitter de la responsabilité qui lui a été ainsi conférée ". Il résulte de ceci que le paragraphe 4 que vous invoquez ne peut être interprété dans le sens d'une suppression de votre obligation - de fournir à ce gouvernement l'assistance militaire dont il a besoin *, sur toute l'étendue du territoire de la République, y compris le Katanga. Cette troisième intervention du Conseil de Sécurité a, au contraire, comme but particulier de préciser que le Katanga tombait bien sous l'application de la résolution du 14 juillet 1960.

Vous basez votre interprétation personnelle sur des cas précédents, notamment celui du Liban et de la Hongrie. Cette façon de procéder ne pourrait être acceptée que dans le cas où les résolutions seraient identiques. Contrairement à ce que vous avancez, ce n'est pas parce que la loi fondamentale serait actuellement la constitution légale de la République que l'O.N.U. a l'obligation de la défendre, mais bien parce que le Conseil de Sécurité en a ainsi décidé dans sa résolution du 14 juillet.

Dans sa résolution du 22 juillet 1960, le Conseil de Sécurité confirme d'ailleurs formellement et en toutes lettres la disposition controversée de la loi fondamentale, notamment l'intégrité territoriale de la République. Nous devons conclure de votre interprétation que l'O.N.U. n'avait pas pour mission de rétablir l'ordre légal au Congo ni de procéder à la pacification du pays comme mon gouvernement l'a demandé, mais se limiterait uniquement à assurer le retrait des troupes belges.

Mon gouvernement proteste par la même occasion contre le fait qu'à votre retour de New York, en route pour le Katanga, vous ne l'avez pas consulté, comme le prescrit la résolution du 14 juillet 1960 , et ceci, malgré la demande à vous faite par la délégation de mon gouvernement d'une façon formelle à New York, avant votre départ, et malgré ma lettre répondant à votre télégramme à ce sujet.

Par contre, vous avez traité avec le Gouvernement rebelle du Katanga en contravention avec la résolution du 14 juillet 1960 du Conseil de Sécurité.

En effet, cette résolution ne vous permet d'entrer en rapport avec les autorités locales qu'après consultation préalable de mon gouvernement.

Vous agissez, au contraire, comme si mon gouvernement, détenteur de l'autorité légale et seul qualifié à traiter avec l'O.N.U., n'existait pas.

Votre façon d'agir jusqu'à présent ne fait que retarder le rétablissement de l'ordre dans la République, particulièrement dans la province du Katanga, alors que le Conseil de Sécurité a déclaré solennellement que le but de l'intervention est le plèn rétablissement de l'ordre dans la République du Congo (voir en particulier la résolution du 22 juillet 1960). En outre les conversations que vous venez d'avoir avec M. Moise Tshombé, les assurances que vous lui avez données et les déclarations qu'il vient de faire à la presse montrent à suftisance que vous vous constituez partie dans le contlit qui, oppose le Gouvernement rebelle du Katanga au Gouvernement légal de l.ı Républiquee, que vous intervenez dans ce conflit et que vous utilisez les forces de l'O.N.U. pour en influencer l'issue, ce qui est formellement interdit précisément par le pir:!graphe que vous invoquez.

Je ne comprends pas que vous ayez envoyé uniquement des troupes suédoises et irlandaises au Katanga en écartant systématiquement celles appartenant aux Ĺtats 
africains, alors que plusieurs de celles-ci furent les premières à debarquer a Léopoldville. Vous avez agi en ceci en connivence avec le Gouvernement rebelle du Katanga et sur l'instigation du Gouvernement belge. Suite à ce qui précède, je me permets de vous demander ce qui suit :

1. De faire assurer la garde de tous les aérodromes de la République par des troupes de l'armée nationale et de la police congolaise en remplacement des troupes de l'O.N.U. 2. D'envoyer immédiatement des troupes marocaines, guinéennes, ghanéennes, éthiopiennes, maliennes, tunisiennes, soudanaises, libériennes et congolaises au Katanga. 3. De mettre des avions à la disposition du Gouvernement de la République pour le transport des troupes congolaises et des civils chargés du rétablissement de l'ordre à travers le pays.

4. De procéder immédiatement à la saisie de toutes les armes et munitions distribuées par des Belges au Katanga aux partisans du gouvernement rebelle - Congolais ou étrangers - et de mettre à la disposition du Gouvernement de la République les armes et les munitions ainsi saisies, celles-ci étant la propriété du Gouvernement.

5. De retirer immédiatement du Katanga toutes les troupes non africaines.

J'espère que vous marquerez votre accord à ce qui précède. Dans le cas où satisfaction ne serait pas donnée à mon gouvernement, celui-ci se verrait dans l'obligation de prendre d'autres dispositions.

Mon gouvernement profite de l'occasion pour remercier le Conseil de Sécurité des résolutions prises qui rencontrent son approbation unanime ainsi que celle du peuple congolais et qu'ils désirent voir appliquer sans retard ni détours.

Veuillez agréer, Monsieur le Secrétaire Général, l'expression de ma haute considération.

Le Premier Ministre

Signe: Patrice Lumumba

\section{Lettrb en date du 15 aOUt 1960 adressíb au Premier Ministre de la Rápublique du Congo par la Secrttaire Géntéral}

J'ai bien reçu votre lettre de cette date. J'y trouve des allégations contre le Secrétuire Général aussi bien que des objections faites à l'interprétation du Secrétaire Général des résolutions dont il est chargé de l'exécution. Dans votre lettre vous présentez aussi certaines demandes qui semblent découler d'une prise de position contraire à l'interprétation que j’ai donnée aux résolutions.

Je n'ai aucune raison d'entrer ici en discussion ni en ce qui concerne les allégations non fondées et injustifiées, ni en ce qui concerne l'interprétation des résolutions du Conseil de Sécurité.

Comme la lettre est une communication officiclle, je vais la faire distribuer aujourd'hui méme comme document du Conseil de Sécurité. Au cas où le Conseil estimerait nécessaire une prise de position sur les actions que j'ai prises, ou l'interprétation que j'ai donnée à ces décisions, je suis prêt à présenter les commentaires personnellement à une session du Conseil. J'espère que si une telle session est convoquée, vous jugerez bon aussi de présenter votre cas personnellement au Conseil. En ce qui concerne les actions demandées par vous, je suivrai naturellement les instructions que le Conseil pourrait trouver nécessaire ou utile de me donner.

J'observe que vous n'avez pas fait mention de ma lettre d'hier soir au Ministre des Affaires étrangères demandant une occasion de faire rapport au Gouvernement de la République du Congo sur l'état de la mise en ouvre des résolutions du Conseil de Sécurité. J'attends encore une réponse à cette proposition. La lettre d'hier au Ministre des Affaires étrangères, aussi bien que ma présente réponse, seront incluses dans les documents distribués au Conseil de Sécurité. 
Veuillez agréer, Monsieur le Premier Ministre, les assurances de ma très haute considération.

\author{
Le Secrétaire Général des Nations Unies \\ Signé: Dag Hammarskjold
}

\title{
4. Lettre en date du 15 aOut 1960 adressée au Secrétaire Général par le Premirr Ministre de la République du Congo
}

J'ai l'honneur d'accuser réception de votre lettre de ce jour. La lettre que je vous ai adressée le 14 août 1960 au nom du Gouvernement de la République du Congo ne contient nullement des allégations contre le Secrétaire Général des Nations Unies mais au contraire, elle révèle des vérités qui doivent être signalées au Conseil de Sécurité et à l'opinion internationale. Le Gouvernement de la République sait pertinemment bien que vos prises de position ne sont nullement celles du Conseil de Sécurité auquel il n'a cessé de faire confiance. Il est paradoxal de constater, que c'est qu'après avoir pris des arrangements avec Monsieur Tshombé et les Belges qui l'entourent, que vous vous décidez à faire rapport au Gouvernement de la République. Ėn outre, vous n'avez jamais jugé utile de consulter le Gouvernement de la République comme vous le recommande la résolution du Conseil de Sécurité. Le gouvernement constate que vous refusez de lui donner l'assistance militaire dont il a besoin et qui a motivé sa démarche aux Nations Unies. Je vous saurais gré de me préciser en termes clairs si vous rejetez les propositions concrètes contenues dans ma lettre du 14 août 1960.

Dans l'attente d'être fixé par retour, je vous prie d'agréer, Monsieur le Secrétaire Général, l'assurance de ma très haute considération.

Le Premier Ministre

Signé: P. Lumumba

\section{Lettre en date du 15 aOUT 1960 adressée au Premier Ministre de la République du Congo par le Secrétaire Général}

J'ai bien reçu votre lettre du 15 août en réponse à ma lettre du même jour. Je suppose que vos lettres ont été approuvées par le Conseil des Ministres et que vous ferez part au Conseil des Ministres de mes réponses. Je n'ai rien à ajouter à ma réponse à votre première communication datée du 14 août et reçue aujourd'hui, à midi. Votre lettre sera distribuée immédiatement à ma demande au Conseil de Sécurité. Si le Conseil des Ministres ne prend pas une initiative qui me ferait changer mes plans, ou n'a pas d'autres propositions concrètes à faire, je me rendrai ce soir à New York afin d'arriver à une clarification des attitudes du Conseil de Sécurité.

Vous avez dû observer que les renseignements sur le déploiement de la force de l'O.N.U. au Katanga indiquent que ce que vous avez dit à ce sujet est crroné. Aussi vous avez du observer que l'aide-mémoire d'interprétation du paragraphe 4 de la résolution du 9 août a été présenté au Conseil de Sécurité et qu'aucun membre du Conseil n'a pris l'initiative d'en contester la validité.

Veuillez agréer, Monsieur le Premier Ministre, les assurances de ma très haute considération.

\section{Le Secrétaire Général des Nations Unies} Signé: Dag Hammarskjold

\section{Lettre en date du 15 aOUt 1960 adressée au Secrétaire Gént́rai. par le Premier Ministre de la République du Congo}

Je viens de recevoir à l'instant votre lettre de ce jour, répondant à celle que je vous ai envoyé, il y a une heure. Votre lettre ne répond pas du tout aux questions précises 
ni aux propositions concrètes contenues dans mes lettres du 14 et du 15 courant. Il n'y a rien qui soit erroné dans mes affirmations, comme vous le déclarez. C'est parce que j'ai dénoncé publiquement, au cours d'une récente conférence de presse, les manquuvres qui consistaient à n'envoyer au Katanga que des troupes de Suede - ce pays dont l'opinion publique sait les affinités particulières avec la famille royale belge - que vous venez de décider précipitamment l'envoi des troupes africaines dans cette province.

Si aucun membre du Conseil de Sécurité n'a pris l'initiative de contester la validité de votre aide-mémoire et de vos plans d'action, c'est parce que les membres du Conseil ne connaissent pas exactement ce qui se trame dans les coulisses. L'opinion publique sait - les membres du Conseil de Sécurité le savent également - qu'après le vote de la dernière résolution, vous avez retardé votre voyage au Congo de 24 heures dans le seul but d'engager des entretiens avec Monsieur Pierre Wigny, Ministre des Affaires étrangères de Belgique. Administrateur des sociétés minières au Congo et un des comploteurs de la sécession du Katanga.

Avant de quitter New York pour le Congo, la délégation congolaise, conduite par le Vice-Président du Conseil, Monsieur Antoine Gizenga, vous a demandé avec insistance de contacter mon gouvernement dès votre arrivée à Léopoldville et ce, avant de vous rendre au Katanga. Ceci en conformité avec la résolution du Conseil de Sécurité du 14 juillet 1960. J'ai personnellement insisté sur ce point, dans la lettre que je vous ai adressée le 12 août, par l'intermédiaire de votre représentant spécial, Monsieur Ralph Bunche. Ignorant complètement le Gouvernement légal de la République, vous avez adressé, de New York, un télégramme à Monsieur Tshombé, Chef de la rébellion katangaise et émissaire du Gouvernement belge. Monsieur Tshombé, toujours sur l'instigation des Belges qui ont été placés à ses côtés, a répondu à ce télégramme, en vous posant deux conditions qui, selon lui, conditionnaient l'entrée des troupes de l'O.N.U. au Katanga. Selon des révélations qui viennent d'être faites par Monsieur 'Tshombé au cours de sa conférence de presse, vous avez entièrement acquiescé aux exigences des Belges, formulées par la voix de Monsieur Tshombé.

Vu tout ce qui précède, le Gouvernement et le peuple du Congo ont perdu leur confiance au Secrétaire Général des Nations Unies. En conséquence, nous demandons ce jour au Conseil de Sécurité d'envoyer immédiatement au Congo un groupe d'observateurs neutres représentant les pays suivants : Maroc, Tunisie, Eithiopie, Ghana, Guinée, République arabe unie, Soudan, Ceylan, Libéria, Mali, Birmanie, l'Inde, Afghanistan et le Liban. Ces observateurs auront pour mission d'assurer l'application immédiate et intégrale des résolutions du Conseil de Sécurité des 14 et 22 juillet et du 9 août 1960.

J'espère fermement que le Conseil de Sécurité en qui nous plaçons toute notre confiance accédera à notre demande légitime. Une délégation du gouvernement vous accompagnera pour exposer au Conseil de Sécurité son point de vue. Je vous demande, en conséquence, de bien vouloir retarder votre départ de 24 heures pour permettre à notre délégation de prendre place dans le même avion.

Veuillez agréer, Monsieur le Secrétaire Général, l'assurance de notre très haute considération.

Le Premier Ministre

Signé: P. Lumumba.

\section{Lettre en date du 15 aOut 1960 adressét au PremirR Ministre de la Répubi.jQue du Congo par l.e Secrétaire Général}

Votre troisième lettre de ce jour vient d'être reçue. J'ai pris acte de vos intentions d'envoyer une délégation au Conseil de Sécurité pour demander l'envoi d'un groupe d'observateurs pour assurer la mise en cuvre de la résolution du Conseil. F́videmment, 
cette demande se base sur la déclaration que vous faites et selon laquelle vous n'avez plus confiance en moi. Je laisse de côté les allégations erronées répétées et lés nouvelles allégations ajoutées à celles que vous m'avez déjà adressées. Il appartient au Conseil de Sécurité de juger de leur valcur aussi bien que de la confiance des pays Membres dans le Secrétaire Général de l'Organisation.

En ce qui concerne les questions posées par vous dans vos lettres et auxquelles vous dites que vous n'avez pas reçu de réponse, je vous réfère au mémorandum explicatif qui vous a été transmis par $M$. Bunche. Vous y trouverez toutes les indications nécessaires. Vous m'avez demander de retarder mon départ pour rendre possible que la délégation du Congo parte dans le même avion que moi. Je ne vois pas l'avantage que cela aurait, comme il va sans dire qu'une réunion du Conseil ne se tiendra qu'après l'arrivée de votre délégation. Dans ces conditions, et comme j'ai fait tous les préparatifs pour mon départ, je vais partir comme je vous l'ai indiqué dans une lettre antérieure d'aujourd'hui. Evidemment, si en réponse à ma lettre d'hier à $M$. le Ministre des Affiaires étrangères le Président de la République ou le Gouvernement dont il est le chef avait indiqué le désir de s'entretenir avec moi des problèmes à résoudre, j'aurais été heureux de reviser mes plans qui, sauf réserve d'une telle initiative, doivent être gouvernés par mon devoir d'être aussitôt que possible à la disposition des délégations au Siège de l'Organisation.

Veuillez agreer, Monsieur le Premier Ministre, les assurances de ma très haute considération.

Le Secrétaire Général des Nations Unies Signé: Dag HaMmarskJOLD. 